\title{
Role of Demodex folliculorum in dermatology
}

\section{Znaczenie Demodex folliculorum w dermatologii}

Klaudia Dopytalska, Katarzyna Lipa, Piotr Sobolewski, Elżbieta Szymańska, Irena Walecka

Department of Dermatology, Centre of Postgraduate Medical Education, Central Clinical Hospital of MSWiA, Warsaw, Poland

Klinika Dermatologii, Centrum Medyczne Kształcenia Podyplomowego, Centralny Szpital Kliniczny MSWiA, Warszawa, Polska

Dermatol Rev/Przegl Dermatol 2019, 106, 507-514 DOI: https://doi.org/l0.5 | |4/dr.2019.89998

\author{
CORRESPONDING AUTHOR/ \\ ADRES DO KORESPONDENCJI: \\ lek. Klaudia Dopytalska \\ Klinika Dermatologii \\ CMKP/CSK MSWiA \\ ul. Wołowska 137 \\ 02-508 Warszawa, Polska \\ tel.: +48664463641 \\ e-mail: klaudia.dopytalska@ \\ cskmswia.pl
}

\begin{abstract}
Demodex folliculorum and Demodex brevis are commensal mites residing in hair follicles and sebaceous glands on human skin, primarily in seborrhoeic areas, on the scalp, and in the external auditory canals. Demodex mites feed on exfoliated epidermal cells and substances secreted by sebaceous glands. They cause mechanical blocking of follicles, follicular hyperkeratosis, and local inflammation. The prevalence of Demodex folliculorum colonisation in the population may vary between $20 \%$ and $80 \%$ of the population, and it increases with age. Demodex infestation is more common in immunocompromised patients, after application of topical glucocorticosteroids or after immunomodulatory agents. The potential role of Demodex folliculorum mites in the pathogenesis of rosacea, perioral dermatitis, blepharitis, folliculitis, and pityriasis folliculorum has been discussed.
\end{abstract}

\section{STRESZCZENIE}

Nużeńce Demodex folliculorum i Demodex brevis to komensaliczne roztocza bytujące w mieszkach włosowych i gruczołach łojowych na skórze człowieka, głównie w okolicach łojotokowych, na owłosionej skórze głowy i w przewodach słuchowych zewnętrznych. Żywią się złuszczonymi komórkami naskórka oraz wydzieliną gruczołów łojowych. Powodują mechaniczne zablokowanie mieszków włosowych, hiperkeratozę mieszkową oraz miejscowy stan zapalny. Odsetek osób z kolonizacją Demodex folliculorum może wynosić od $20 \%$ do $80 \%$ i wzrasta z wiekiem. Obserwuje się zwiększone występowanie nużeńców u pacjentów z obniżoną odpornością, stosujących miejscowo glikokortykosteroidy lub preparaty immunomodulujące. Podkreśla się możliwą rolę Demodex folliculorum $\mathrm{w}$ patogenezie trądziku różowatego, zapalenia okołoustnego, zapalenia brzegów powiek (blepharitis), zapalenia mieszków włosowych oraz pityriasis folliculorum.

Key words: rosacea, Demodex folliculorum, demodicosis.

Słowa kluczowe: trądzik różowaty, Demodex folliculorum, demodekoza. 


\section{INTRODUCTION}

Demodex spp. mites are arthropods belonging to the order Acari of the class Arachnida. They are commensal organisms residing on the skin of many mammalian species. Two human-specific species of Demodex have been described: Demodex folliculorum and Demodex brevis. Mites at all stages of development feed on exfoliated epidermal cells and sebaceous gland secretions [1, 2]. For this reason, they inhabit primarily seborrhoeic areas of the face (forehead, nose, chin, cheeks), the scalp, and the external auditory canals, and they are less commonly found in genital areas and locations poor in sebaceous glands and hair follicles such as the palms of the hands [3-5]. The colonisation of human skin by Demodex spp. is very common, and it is estimated to occur in $20 \%$ to $80 \%$ of the population depending on age. The development of skin lesions caused by Demodex is associated with an increase in the number of mites on the skin above 5 per $1 \mathrm{~cm}^{2}$ of skin. The role of Demodex spp. in the pathogenesis of skin diseases has not been fully explained. Demodex folliculorum mites have been potentially implicated in the pathogenesis of rosacea, perioral dermatitis, blepharitis, folliculitis, and pityriasis folliculorum $[1,2]$.

\section{CHARACTERISTICS OF DEMODEX SPP.}

Both Demodex folliculorum and Demodex brevis have a wormlike shape, however their length, body form and preferred anatomical sites are different. The anterior body part of Demodex mites, called gnathosoma, contains the mouthparts with chelicerae to cut the epithelial cells of the host skin. The remaining part of the body is divided into prosoma and opisthosoma [6]. Adults and nymphs have 4 pairs of 5-segmented legs, whereas larvae have 3 pairs of legs. The average body length varies between males and females [7].

The optimal conditions for the development of mites are in a humid environment with an acidic $\mathrm{pH}$ and temperatures of $16-20^{\circ} \mathrm{C}$. Demodex mites avoid sunlight, and come to the surface at night in search of mates [8].

The entire life cycle of Demodex mites takes 15 to 21 days, with all stages occurring in a single host [9]. Adult mites mate at the hair follicle openings. A fertilised female mite moves into the sebaceous glands, where it lays approximately 20 eggs. The eggs develop into legless larvae which metamorphose into a form with 3 pairs of legs. The next stage of development is an eight-legged nymph which moults twice, ultimately transforming into the mature form [10].

An adult of the species Demodex folliculorum reaches the length of 300-400 $\mu \mathrm{m}$, and Demodex brevis - 250 $280 \mu \mathrm{m}$ [1]. Demodex folliculorum resides in the hair follicles, where it typically creates clusters of mites.

\section{WPROWADZENIE}

Nużeniec Demodex spp. - przedstawiciel klasy pajęczaków (Arachida), należący do rzędu roztoczy (Acari) jest komensalicznym organizmem bytującymi na skórze wielu gatunków ssaków. Na skórze człowieka opisano występowanie dwóch gatunków - nużeńca ludzkiego (Demodex folliculorum) oraz nużeńca krótkiego (Demodex brevis). Roztocza we wszystkich stadiach rozwoju żywią się złuszczonymi komórkami naskórka oraz wydzieliną gruczołów łojowych [1, 2]. Z tego powodu zasiedlają przede wszystkim okolice łojotokowe skóry twarzy (czoło, nos, broda, policzki), owłosioną skórę głowy oraz przewody słuchowe zewnętrzne, rzadziej okolice genitalne oraz lokalizacje ubogie w gruczoły łojowe i mieszki włosowe, takie jak skóra rąk [3-5]. Kolonizacja skóry człowieka Demodex spp. jest bardzo częsta i wynosi w zależności od wieku 20-80\%. Obecność zmian skórnych wywołanych przez nużeńce wiąże się ze zwiększeniem liczby osobników na skórze powyżej 5 roztoczy na $1 \mathrm{~cm}^{2}$ skóry. Udział Demodex spp. w patogenezie chorób skóry nie został w pełni poznany. Podkreśla się możliwą rolę D. folliculorum w rozwoju trądziku różowatego, zapalenia okołoustnego, zapalenia brzegów powiek (blepharitis), zapalenia mieszków włosowych i pityriasis folliculorum [1, 2].

\section{CHARAKTERYSTYKA DEMODEX SPP.}

Demodex folliculorum oraz Demodex brevis mają robakowaty kształt, różnią się długością, budową ciała oraz miejscem bytowania. W przedniej części ciała nużeńca, czyli ganthosoma, znajduje się aparat gębowy wyposażony w szczękoczułki służące do przecinania komórek nabłonka gospodarza. Resztę ciała stanowią podosoma i opithosoma [6]. Postacie dorosłe oraz nimfy mają cztery pary pięcioczłonowych odnóży, natomiast larwy trzy pary odnóży. Średnia długość ciała różni się u osobników męskich i żeńskich [7].

Optymalne warunki do rozwoju nużeńców panują w wilgotnym środowisku o kwaśnym $\mathrm{pH}$ i temperaturze $\mathrm{w}$ zakresie $16-20^{\circ} \mathrm{C}$. Roztocza unikają światła słonecznego, nocą wychodzą na powierzchnię skóry w celu poszukiwania partnera do rozrodu [8].

Cykl rozwojowy nużeńca trwa 15-21 dni i zachodzi u jednego żywiciela [9]. Kopulacja osobników dorosłych odbywa się w okolicy ujść mieszków włosowych. Zapłodniona samica przemieszcza się do wnętrza gruczołów łojowych, gdzie składa około 20 jaj. Z jaj wylęgają się początkowo beznożne larwy, które ulegają przeobrażeniu w postać z trzema parami odnóży. Kolejnym stadium rozwojowym jest ośmionożna nimfa, która przechodzi kolejne dwa linienia, przeobrażając się w postać dojrzałą [10].

Dorosły osobnik z gatunku D. folliculorum osiąga długość 300-400 $\mu \mathrm{m}$, natomiast $D$. brevis - 250-280 $\mu \mathrm{m}$ [1]. Demodex folliculorum, czyli nużeniec ludzki, bytuje w mieszkach włosowych, zwykle tworząc skupiska. 
It may also reside in the sebaceous glands of Zeis. Demodex brevis tends to present individually, deep in the sebaceous glands, causing their destruction. In addition, Demodex brevis mites may be found in meibomian glands [6]. The number of mites residing on the skin increases during the warm months. Infection occurs both through direct contact with the host and by sharing bedding, towels and cosmetics [5]. The presence of Demodex eggs has also been found in house dust [11].

\section{EPIDEMIOLOGY}

Skin colonisation by Demodex spp. occurs in all human races at every latitude [12]. The prevalence of Demodex folliculorum colonisation in the population may vary between $20 \%$ and $80 \%$, and it rises with age [13]. No evidence of neonatal skin infestation by $\mathrm{De}$ modex spp. has been found. Colonisation of the skin in humans usually takes place in childhood or early adulthood [14]. Demodex spp. mites can spread to the infant's skin through direct exposure to the mother's colonised skin $[15,16]$. There is a confirmed association between the prevalence of Demodex infection and age. The fact that children are Demodex spp. carriers less commonly than adults may be due to a lower activity of their sebaceous glands [17-19].

The association between the prevalence of colonisation and sex is controversial. No such relationship was found by Zhao et al. in studies conducted among a group of subjects aged 13 to 22 years [20]. Raszeja-Kotelba et al. found a higher intensity of skin colonisation by Demodex spp. in women than in men, which they attributed to more frequent use of creams and powders by women [5]. Forton et al. also showed a higher prevalence of Demodex spp. in women, which, according to the researchers, was due to the effects of female sex hormones [21]. In contrast, Horvath et al. found that men were carriers of Demodex spp. more frequently than women [22].

Also, the prevalence of Demodex spp. was greater among immunocompromised patients - with haematological disorders undergoing chemotherapy, HIV infection, and with chronic renal failure during dialysis treatment [15, 16, 23]. An increased number of Demodex mites was also observed in patients with perioral dermatitis using topical glucocorticosteroids or immunomodulatory agents [24]. It has been highlighted that the average density of mites per $1 \mathrm{~cm}^{2}$ is significantly higher on the skin of patients with rosacea - both the erythematotelangiectatic and papulopustular forms of the disorder [24-27].

\section{DEMODEX SPP. IN SKIN DISEASES}

Demodex spp. infestation often remains asymptomatic. The development of skin lesions caused by
Może zasiedlać również gruczoły łojowe Zeissa. Demodex brevis, czyli nużeniec krótki, występuje najczęściej pojedynczo, głęboko w gruczołach łojowych, co powoduje ich zniszczenie. Ponadto może pasożytować w gruczołach Meiboma [6]. Liczba roztoczy bytujących na skórze zwiększa się podczas ciepłych miesięcy. Do zarażenia dochodzi zarówno poprzez bezpośredni kontakt z nosicielem, jak i przez korzystanie ze wspólnej pościeli, ręczników oraz kosmetyków [5]. Obecność jaj nużeńców stwierdzono również w kurzu [11].

\section{EPIDEMIOLOGIA}

Kolonizacja skóry przez Demodex spp. obserwowana jest u przedstawicieli wszystkich ras ludzkich, na każdej szerokości geograficznej [12]. Odsetek osób z kolonizacją D. folliculorum może wynosić $20-80 \%$ i wzrasta z wiekiem [13]. Nie stwierdzono obecności osobników Demodex spp. na skórze noworodków. Do zarażenia dochodzi najczęściej w okresie dzieciństwa lub wczesnej dorosłości [14]. Możliwe jest przeniesienie osobników Demodex spp. na skórę niemowląt przez kontakt bezpośredni ze skolonizowaną skórą matki $[15,16]$. Potwierdzono zależność między częstością zarażenia nużeńcem a wiekiem. Rzadsze nosicielstwo Demodex spp. u dzieci niż u dorosłych może być związane z mniejszą aktywnością gruczołów łojowych [17-19].

Istnieją kontrowersje dotyczące zależności między częstością kolonizacji a płcią. Zhao i wsp. nie stwierdzili takiej zależności w badaniach przeprowadzonych w grupie osób w wieku 13-22 lat [20]. Raszeja-Kotelba i wsp. wykazali większą kolonizację Demodex spp. na skórze kobiet niż mężczyzn ze względu na częstsze stosowanie przez kobiety pudrów i kremów [5]. Forton i wsp. również stwierdzili większą częstość występowania Demodex spp. u kobiet, co według badaczy było spowodowane wpływem hormonów płciowych [21]. Horvath i wsp. wykazali częstsze nosicielstwo Demodex spp. u mężczyzn niż u kobiet [22].

Stwierdzono częstsze występowanie Demodex spp. u pacjentów z obniżoną odpornością - z zaburzeniami hematologicznymi w trakcje chemioterapii, zakażonych HIV oraz z przewlekłą niewydolnością nerek w trakcie dializoterapii [15, 16, 23]. Zwiększoną liczbę nużeńców zaobserwowano także $\mathrm{u}$ chorych $\mathrm{z}$ zapaleniem okołoustnym, stosujących miejscowe glikokortykosteroidy lub preparaty immunomodulujące [24]. Podkreśla się istotnie większą średnią liczbę nużeńców na $1 \mathrm{~cm}^{2}$ skóry u chorych z trądzikiem różowatym - zarówno w postaci rumieniowo-teleangiektatycznej, jak i grudkowo-krostkowej [24-27].

\section{DEMODEX SPP. W CHOROBACH SKÓRY}

Kolonizacja Demodex spp. przebiega często bezobjawowo. Obecność zmian skórnych wywołanych przez 


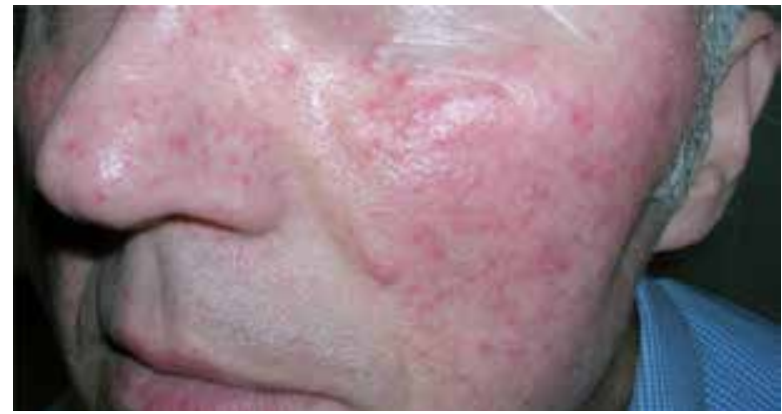

Figure I. Skin manifestations of rosacea accompanied by Demodex folliculorum infection

Rycina I. Zmiany skórne w przebiegu trądziku różowatego z towarzyszącym zakażeniem Demodex folliculorum

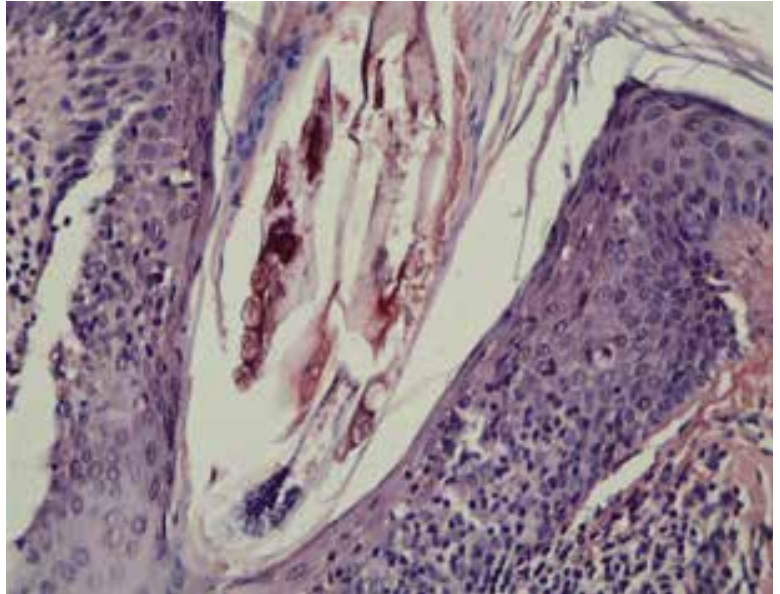

Figure 2. Histopathological examination of a skin specimen revealing Demodex folliculorum in a hair follicle

Rycina 2. Demodex folliculorum widoczny w mieszku włosowym w badaniu histopatologicznym wycinka skóry

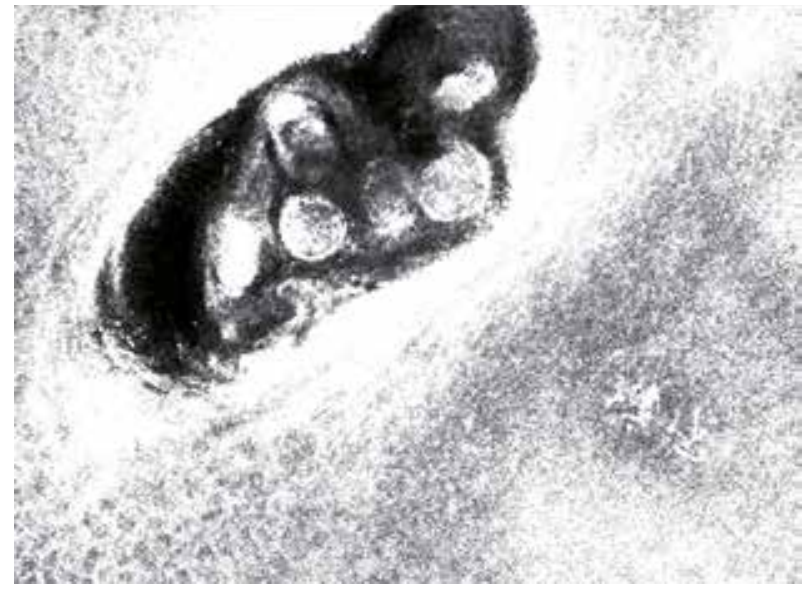

Figure 3. Reflectance confocal microscopy image showing Demodex folliculorum in the opening of a hair follicle

Rycina 3. Demodex folliculorum widoczny w ujściu mieszka włosowego w badaniu metodą refleksyjnej mikroskopii konfokalnej

Demodex is associated with an increase in the number of mites on the skin above 5 per $1 \mathrm{~cm}^{2}$ of skin. Demodex spp. mites have been potentially implicated in the pathogenesis of rosacea, perioral dermatitis, blepharitis, folliculitis, and pityriasis folliculorum [1-6]. Infection with Demodex spp. gives rise to a variety of skin manifestations such as erythema, dry skin, perifollicular scaling, hyperpigmentation, erythematous-papular lesions, or itchy skin. A more severe course of infection can be associated with conditions of compromised immunity [21, 23-26]. Demodicosis of the eyelids presents as redness of the eyelids and conjunctiva accompanied by itching, burning, and increased tear production. Demodex infection may lead to the loss of eyelashes and eyebrows [28].

Demodex spp. mites reside in hair follicles and sebaceous glands, causing their mechanical blockage, nużeńce wiąże się ze zwiększeniem liczby osobników na skórze powyżej 5 roztoczy na $1 \mathrm{~cm}^{2}$ skóry. Podkreśla się możliwy udział Demodex spp. w patogenezie trądziku różowatego, zapalenia okołoustnego, zapalenia brzegów powiek (blepharitis), zapalenia mieszków włosowych i pityriasis folliculorum [1-6]. Zakażenie Demodex spp. powoduje różnorodne objawy skórne, takie jak rumień, suchość skóry, łuszczenie przymieszkowe, hiperpigmentacje, wykwity rumieniowo-grudkowe lub świąd skóry. Cięższy przebieg infekcji może być związany ze stanami obniżonej odporności [21, 23-26]. W demodekozie powiek obserwuje się zaczerwienienie powiek i spojówek z towarzyszącym świądem, pieczeniem i łzawieniem oczu. Zakażenie nużeńcem może prowadzić do wypadania brwi i rzęs [28].

Demodex spp. bytują w mieszkach włosowych i gruczołach łojowych, co powoduje ich mechaniczne zablo- 
follicular hyperkeratosis, and local inflammation. The presence of chitin in the cuticle of the mite triggers a granulation reaction around the foreign body $[1,8$, $10,21]$. Since the mites feed on epidermal cells, the epidermal barrier is compromised, promoting the penetration of mites into the dermis and activation of Toll-like receptors (TLRs) which are involved in the pathogenesis of rosacea [29]. Demodex spp. antigens stimulate the host's immune system and induce a type IV hypersensitivity reaction [30]. This leads to the proliferation of T cells (Th1/Th17), neutrophils, plasmocytes, histiocytes and giant cells with inflammatory cell infiltration around the hair follicles [30-32]. In addition, Demodex spp. mites promote the transmission of Bacillus oleronius and Bartonella quintana - bacteria residing in the alimentary tract of the mites. Bacillus oleronius is known to be a contributing factor in the development of rosacea by increasing the severity of inflammation. The bacterium synthesises protein antigens, triggering the activation of neutrophils [32-34]. Following the discovery of serine protease inhibitors ( $\alpha 1$-antitrypsin and $\alpha 1$ antichymotrypsin) on the surface of Demodex spp., it is suspected that the mites may have the ability to produce proteases [35].

The primary diagnostic examination in suspected demodicosis is the evaluation of scrapings collected from the skin or eyelashes under a light microscope to visualise Demodex spp. colonies (direct slide method). A useful examination is Standardised Skin Surface Biopsy (SSSB), which can be employed to determine the density of mites per $1 \mathrm{~cm}^{2}$. Histopathological examination of a skin specimen may also be diagnostically helpful [36]. In skin demodicosis, when the density of Demodex exceeds 5 mites per $1 \mathrm{~cm}^{2}$, it is possible to visualise Demodex folliculorum by dermoscopy or videodermoscopy. Characteristic findings include whitish gelatinous thread-like structures, 1 to $3 \mathrm{~mm}$ long, protruding out of the follicular openings (known as "Demodex tails"), which are consistent with penetrating Demodex mites, and dilated hair follicle openings with erythematous margins, filled with a greyish or light brown plug $[37,38]$. Innovative diagnostic methods offering potential benefits in the detection of Demodex spp. on the skin include high-definition optical coherence tomography (HD-OCT) and reflectance confocal microscopy (RCM). They are non-invasive examinations with immediate visualisation, however their application is currently limited because of associated costs and availability [38-40].

\section{TREATMENT}

There are no clearly defined therapeutic standards for skin manifestations associated with Demodex spp. infestation. Available treatment options include me- kowanie, hiperkeratozę mieszkową i miejscowy stan zapalny. Obecność chityny w oskórku roztocza wyzwala odczyn ziarninowy wokół ciała obcego [1, 8, 10, 21]. Odżywianie się nużeńców komórkami naskórka prowadzi do naruszenia bariery naskórkowej, co pozwala na przenikanie roztoczy do skóry właściwej i aktywację receptorów Toll-like (TLR) biorących udział w patogenezie trądziku różowatego [29]. Antygeny Demodex spp. stymulują układ immunologiczny gospodarza i indukują reakcję nadwrażliwości typu IV [30]. Prowadzi to do proliferacji limfocytów T (Th1/Th17), neutrofilów, plazmocytów, histiocytów i komórek olbrzymich z naciekami komórek zapalnych wokół mieszków włosowych [30-32]. Dodatkowo Demodex spp. umożliwia transmisję bakterii Bacillus oleronius i Bartonella quintana, które egzystują w przewodzie pokarmowym nużeńca. Bacillus oleronius odgrywa rolę w rozwoju trądziku różowatego poprzez nasilenie stanu zapalnego. Bakteria ta syntetyzuje antygeny białkowe, co powoduje aktywacje granulocytów obojętnochłonnych [32-34]. Ze względu na odkrycie na powierzchni Demodex spp. inhibitorów surowiczych proteaz ( $\alpha 1$-antytrypsyny i $\alpha 1$-antychymotrypsyny) przypuszcza się, że nużeńce mogą mieć zdolność do produkcji proteaz [35].

Podstawą diagnostyki przy podejrzeniu demodekozy jest badanie zeskrobin skóry lub rzęs pod mikroskopem świetlnym, które pozwala uwidocznić kolonie Demodex spp. (metoda preparatu bezpośredniego). Użytecznym badaniem jest standaryzowana biopsja powierzchni skóry (SSSB), dzięki której możliwe jest określenie gęstości nużeńców na skórze. Pomocne może być także badanie histopatologiczne wycinka skóry [36]. W demodekozie skóry, kiedy gęstość nużeńców przekracza 5 osobników na $1 \mathrm{~cm}^{2}$, można uwidocznić osobniki D. folliculorum w badaniu dermoskopowym lub wideodermoskopowym. Charakterystyczne są widoczne w ujściach mieszków włosowych galaretowate, białawe, nitkowate struktury o długości 1-3 mm (Demodex tails), odpowiadające penetrującym nużeńcom, oraz poszerzone ujścia mieszków włosowych z rumieniową otoczką, wypełnione szarawym lub jasnobrązowym czopem [37, 38]. Do innowacyjnych metod diagnostycznych, które mogą być przydatne w wykrywaniu Demodex spp. na skórze, należą optyczna tomografia koherencyjna o wysokiej rozdzielczości (high-definition optical coherence tomography - HD-OCT) oraz refleksyjna mikroskopia konfokalna (reflectance confocal microscopy - RCM). Są to badania nieinwazyjne $z$ natychmiastową wizualizacją, jednak ze względu na koszty i dostępność obecnie mają ograniczone zastosowanie [38-40].

\section{LECZENIE}

Nie ma jednoznacznych standardów terapeutycznych w objawach skórnych związanych z zakażeniem Demodex spp. Zastosowanie znalazły preparaty $\mathrm{z}$ iwer- 
dicinal products based on ivermectin, metronidazole or permethrin. Oral ivermectin has been used in the treatment of demodicosis for a long time [2, 41]. Topical ivermectin ( $1 \%$ cream) has been shown to be effective in the treatment of rosacea, pityriasis folliculorum and blepharitis. In addition to its antiparasitic effect, ivermectin also has antiinflammatory properties. It reduces the synthesis of various pro-inflammatory cytokines such as tumor necrosis factor $\alpha$ and interleukins $1 b, 6,8$, and inhibits the expression of cathelicidins LL-37 involved in the pathogenesis of rosacea. Based on its antiparasitic activity, ivermectin induces a reduction in the number of Demodex folliculorum on the skin. Ivermectin opens the glutamategated chloride channels in the nerve and muscle cells of Demodex mites. This leads to an increased influx of chloride ions into these cells, which causes their hyperpolarisation leading to the dysfunction of the nervous and muscular systems, and the death of the parasite [40-43]. Treatment based on $1 \%$ cream with ivermectin has been shown to reduce the number of mites by $99 \%$ in vivo during a period of 12 weeks [44]. The effect of metronidazole on Demodex spp. has not been fully elucidated, but its topical preparations offer benefits in the treatment of blepharitis caused by the mites, and reduce inflammatory lesions in rosacea. Metronidazole has antiinflammatory effects, inhibits the formation of reactive oxygen species, and reduces oxidative stress and the production of free radicals. Better therapeutic effects are obtained when metronidazole is used in combination with a topical ivermectin preparation $[37,45,46]$.

\section{CONFLICT OF INTEREST}

The authors declare no conflict of interest. mektyną, metronidazolem i permetryną. Doustny preparat iwermektyny był stosowany od dawna w leczeniu demodekozy $[2,41]$. Miejscowa iwermektyna w postaci kremu o stężeniu 1\% okazała się skuteczna w terapii trądziku różowatego, pityriasis folliculorum oraz blepharitis. Poza efektem przeciwpasożytniczym iwermektyna ma także działanie przeciwzapalne. Zmniejsza syntezę cytokin prozapalnych, takich jak czynnik martwicy nowotworów $\alpha$ oraz interleukiny $1 \beta, 6,8$, oraz hamuje ekspresje katelicydyn LL-37, które biorą udział w patogenezie rosacea. Działając przeciwpasożytniczo, sprzyja redukcji liczby organizmów $D$. folliculorum na skórze. Iwermektyna powoduje otwarcie glutaminozależnych kanałów chlorkowych w komórkach nerwowych i mięśniowych nużeńca. Powoduje to wzmożony napływ jonów chlorkowych do tych komórek, co wywołuje ich hiperpolaryzację i prowadzi do zaburzenia funkcjonowania układu nerwowego i mięśniowego oraz do śmierci pasożyta [40-43]. Stwierdzono redukcję o 99\% liczby nużeńców in vivo w czasie 12 tygodni terapii kremem z iwermektyną o stężeniu 1\% [44]. Działanie metronidazolu na Demodex spp. nie zostało w pełni poznane, jednak jego miejscowe preparaty przynoszą korzyści w leczeniu zapalenia brzegów powiek wywołanych przez nużeńce oraz redukcji zmian zapalnych $\mathrm{w}$ trądziku różowatym. Metronidazol ma działanie przeciwzapalne, hamuje powstawanie reaktywnych form tlenu, redukuje stres oksydacyjny oraz powstawanie wolnych rodników. Lepsze efekty terapeutyczne uzyskuje się w leczeniu skojarzonym $\mathrm{z}$ miejscowym preparatem iwermektyny $[37,45,46]$.

\section{KONFLIKT INTERESÓW}

Autorzy nie zgłaszają konfliktu interesów.

\section{References \\ Piśmiennictwo}

1. Rusiecka-Ziółkowska J., Nokiel M., Fleischer M.: Demodex - an old pathogen or a new one? Adv Clin Exp Med 2014, 23, 295-298.

2. Chen W., Plewig G.: Human demodicosis: revisit and a proposed classification. Br J Dermatol 2014, 170, 1219-1225.

3. Wesołowska M., Baran W., Szepietowski J., Hirschberg L., Jankowski S.: Demodicidosis in humans as a current problem in dermatology. Wiad Parazytol 2005, 51, 253-256.

4. Kuźna-Grygiel W., Kosik-Bogacka D., Czepita D., Sambor I.: Symptomatic and asymptomatic infections of Demodex spp. in eye lashes of patients of different age groups. Wiad Parazytol 2004, 50, 55-61.

5. Raszeja-Kotelba B., Jenerowicz D., Izdebska J., Bowszyc-Dmochowska M., Tomczak M., Dembińska M.: Some aspects of the skin infestation by Demodex folliculorum. Wiad Parazytol 2004, 50, 41-54. 
6. Jing X., Shuling G., Ying L.: Environmental scanning electron microscopy observation of the ultrastructure of Demodex. Microsc Res Tech 2005, 68, 284-289.

7. Desch C., Nutting W.: Demodex folliculorum (Simon) and D. brevis akbulatova of man: redescription and reevaluation. J Parasitol 1972, 58, 169-177.

8. Lacey N., Ní Raghallaigh S., Powell F.: Demodex mites - commensals, parasites or mutualistic organisms? Dermatology 2011, 222, 128-130.

9. Wesolowska M., Knysz B., Reich A., Blazejewska D., Czarnecki M., Gladysz A., et al.: Prevalence of Demodex spp. in eyelash follicles in different populations. Arch Med Sci 2014, 10, 319-324.

10. Jarmuda S., O'Reilly N., Zaba R., Jakubowicz O., Szkaradkiewicz A., Kavanagh K.: Potential role of Demodex mites and bacteria in the induction of rosacea. J Med Microbiol 2012, 61, 1504-1510.

11. Czepita D., Kuźna-Grygiel W., Czepita M., Grobelny A.: Demodex folliculorum and Demodex brevis as a cause of chronic marginal blepharitis. Ann Acad Med Stetin 2007, 53, 63-67.

12. Lacey N., Kavanagh K., Tseng S.: Under the lash: Demodex mites in human diseases. Biochem 2009, 31, 2-6.

13. Elston D.: Demodex mites: facts and controversies. Clin Dermatol 2010, 28, 502-504.

14. Bonnar E., Eustace P., Powell F.: The Demodex mite population in rosacea. J Am Acad Dermatol 1993, 28, 443-448,

15. Karincaoglu Y., Esrefoglu Seyhan M., Bayram N., Aycan O., Taskapan H.: Incidence of Demodex folliculorum in patients with end stage chronic renal failure. Ren Fail 2005, 27, 495-499.

16. Seyhan M.E., Karincaoğlu Y., Bayram N., Aycan O., Kuku I.: Density of Demodex folliculorum in haematological malignancies. J Int Med Res 2004, 32, 411-415.

17. Norn M.: Demodex folliculorum. Br J Ophthalmol 1972, 56, 140.

18. Roth A.: Demodex folliculorum in hair follicles of eyelid skin. Ann Ophthalmol 1979, 11, 37-40.

19. Kamoun B., Fourati M., Feki J., Mlik M., Karray F., Trigui A., et al.: Blepharitis due to Demodex: myth or reality? J Fr Ophtalmol 1999, 22, 525-527.

20. Zhao Y., Guo N., Xun M., Xu J., Wang M., Wang D.: Sociodemographic characteristics and risk factor analysis of Demodex infestation (Acari: Demodicidae). J Zhejiang Univ Sci B 2011, 12, 998-1007.

21. Forton F., Germaux M., Brasseur T., De Liever A., Laporte M., Mathys C., et al.: Demodicosis and rosacea: epidemiology and significance in daily dermatologic practice. J Am Acad Dermatol 2005, 52, 74-87.

22. Horváth A., Neubrandt D., Ghidán Á., Nagy K.: Risk factors and prevalence of Demodex mites in young adults. Acta Microbiol Immunol Hung 2011, 58, 145-155.

23. Aquilina C., Viraben R., Sire S.: Ivermectin-responsive Demodex infestation during human immunodeficiency virus infection. A case report and literature review. Dermatology 2002, 205, 394-397.

24. Fujiwara S., Okubo Y., Irisawa R., Tsuboi R.: Rosaceiform dermatitis associated with topical tacrolimus treatment. J Am Acad Dermatol 2010, 62, 1050-1052.

25. Erbagc Z., Ozgoztas O.: The significance of Demodex folliculorum density in rosacea. Int J Dermatol 1998, 37, 421-425.

26. Forton F., Seys B.: Density of Demodex folliculorum in rosacea: a case-control study using standardized skin-surface biopsy. Br J Dermatol 1993, 128, 650-659.

27. Chang Y., Huang Y.: Role of Demodex mite infestation in rosacea: a systematic review and meta-analysis. J Am Acad Dermatol 2017, 77, 441-447.

28. Lacey N., Kavanagh K., Tseng S.: Under the lash: Demodex mites in human diseases. Biochem (Lond) 2009, 31, 2-6.

29. Schauber J., Dorschner R., Coda A., Büchau A., Liu P., Kiken D., et al.: Injury enhances TLR2 function and antimicrobial peptide expression through a vitamin D-dependent mechanism. J Clin Invest 2007, 117, 803-811.

30. Hsu C., Hsu M., Lee J.: Demodicosis: a clinicopathological study. J Am Acad Dermatol 2009, 60, 453-462.

31. Georgala S., Katoulis A., Kylafis G., Koumantaki-Mathioudaki E., Georgala C., Aroni K.: Increased density of Demodex folliculorum and evidence of delayed hypersensitivity reaction in subjects with papulopustular rosacea. J Eur Acad Dermatol Venereol 2001, 15, 441-444.

32. Holmes A., Steinhoff M.: Integrative concepts of rosacea pathophysiology, clinical presentation and new therapeutics. Exp Dermatol 2017, 26, 659-667.

33. O'Reilly N., Bergin D., Reeves E., McElvaney N., Kavanagh K.: Demodex-associated bacterial proteins induce neutrophil activation. Br J Dermatol 2012, 166, 753-760.

34. Lacey N., Delaney S., Kavanagh K., Powell F.: Miterelated bacterial antigens stimulate inflammatory cells in rosacea. Br J Dermatol 2007, 157, 474-481.

35. Tsutsumi Y.: Deposition of IgD, alpha-1-antitrypsin and alpha-1-antichymotrypsin on Demodex folliculorum and Demodex brevis infesting the pilosebaceous unit. Pathol Int 2004, 54, 32-34.

36. Skonieczna D., Sławianowska P., Wesołowski R., Szewczyk-Golec K.: Demodex mites - characteristics, pathogenicity, diagnostics. Diagn Lab 2018, 54, 37-44.

37. Sattler E., Hoffmann V., Ruzicka T., Braunmühl T., Berking C.: Reflectance confocal microscopy for monitoring the density of Demodex mites in patients with rosacea before and after treatment. Br J Dermatol 2015, 173, 69-75.

38. Maier T., Sattler E., Braun-Falco M., Ruzicka T., Berking C.: High-de nition optical co- herence tomography for the in vivo detection of Demodex mites. Dermatology 2012, 225, 271-276.

39. Salem D., El-Shazly A., Nabih N., El-Bayoumy Y., Saleh S.: Evaluation of the efficacy of oral ivermectin in comparison with ivermectin-metronidazole combined therapy in the treatment of ocular and skin lesions of Demodex folliculorum. Int J Infect Dis $2013,17,343-347$

40. Kircik L., Del Rosso J., Layton AM., Schauber J.: Over 25 years of clinical experience with ivermectin: an overview of safety for an increasing number of indications. J Drugs Dermatol 2016, 15, 325-332.

41. Darji K., Burkemper N.: Pityriasis folliculorum: response to topical ivermectin. J Drugs Dermatol 2017, 16, 1290-1292. 
42. Steinhoff M., Vocanson M., Voegel J., Hacini-Rachinel F., Schäfer G.: Topical ivermectin $10 \mathrm{mg} / \mathrm{g}$ and oral doxycycline $40 \mathrm{mg}$ modified-release: current evidence on the complementary use of anti-inflammatory rosacea treatments. Adv Ther 2016, 33, 1481-1501.

43. Del Rosso J.: Topical ivermectin: data supporting dual modes of action in rosacea. Clin Aesthet Dermatol 2017, 10, 39-42.

44. Schaller M., Gonser L., Belge K., Braunsdorf C., Nordin R., Scheu A., et al.: Dual anti-inflammatory and anti-parasitic action of topical ivermectin 1\% in papulopustular rosacea. J Eur Acad Dermatol Venereol 2017, 31, 1907-1911.

45. Narayanan S., Hünerbein A., Getie M., Jäckel A., Neubert R.: Scavenging properties of metronidazole on free oxygen radicals in a skin lipid model system. J Pharm Pharmacol 2007, 59, 1125-1130.

46. Van Zuuren E., Kramer S., Carter B., Graber M., Fedorowicz Z.: Effective and evidence-based management strategies for rosacea: summary of a Cochrane systematic review. Br J Dermatol 2011, 165, 760-781.

Received: 3.03.2019

Accepted: 7.08.2019

Otrzymano: 3.03.2019 r

Zaakceptowano: $7.08 .2019 \mathrm{r}$. 